\title{
CERVICAL SPINE INJURIES CAUSED BY DIVING INTO WATER
}

\author{
By JERZY KIWERSKI, M.D. \\ Spinal Injuries Centre, Konstancin, Poland
}

\begin{abstract}
In 1965-I978, I94 patients with cervical spine injuries, caused by diving into water, were treated. In 182 cases, spinal fracture was accompanied by spinal cord injury. This paper presents mechanism of trauma, in connection with observed degree of neurological disturbances as well as further life of this group of patients in relation to the degree of spinal cord damage.
\end{abstract}

Key words: Diving accidents, classification.

\section{Introduction}

Diving into too shallow water often is a frequent cause of cervical spine injury (Tables I-III).

These traumas usually are complicated by spinal cord injury. This has most tragic consequences because, as a rule, it concerns young people in the second or third decade of their life. Their plans and professional ambitions are at once ruined as a result of unfortunate or thoughtless diving into water. Therefore, in this group of cases, in addition to medical problems, essential questions of a social, and particularly psychological, nature occur (Hall, I978).

\section{Clinical material}

In I965-1978, I94 patients with cervical spine injury, caused by diving into water, were treated in our Institute.

This group constitutes $2 \mathrm{I}$ per cent of treated patients with cervical spine injury in the early post-traumatic period. In this paper we discuss a group of I 82 patients, who, together with spinal fracture, had damage to the spinal cord.

Table I presents mechanism of lesion in relation to the degree of spinal cord injury. The division of spinal cord injury, used by us, does not deviate, in principle, from that proposed by Frankel et al., (1969).

TABLE I

\begin{tabular}{|c|c|c|c|c|c|c|}
\hline \multirow{3}{*}{$\begin{array}{l}\text { Spinal cord } \\
\text { injuries on } \\
\text { admission }\end{array}$} & \multicolumn{5}{|c|}{ Trauma mechanism } & \multirow[t]{3}{*}{ Total } \\
\hline & \multicolumn{2}{|c|}{ Flexion } & \multicolumn{2}{|c|}{ Compressive } & \multirow[t]{2}{*}{ Extension } & \\
\hline & Fracture & Dislocation & Crush & Explosion & & \\
\hline Complete & 34 & I5 & IO & 36 & - & 95 \\
\hline I & 5 & 7 & 9 & 20 & I & 42 \\
\hline 2 & 3 & 2 & 6 & 2 & I & I4 \\
\hline 3 & 4 & 6 & IO & 9 & 2 & $3 I$ \\
\hline Total & 46 & 30 & 35 & 67 & 4 & I 82 \\
\hline
\end{tabular}


We distinguish complete injuries (group A, according to Frankel) including cases with paralysis and abolishment of all kinds of sensation below the level of injury, and partial (incomplete) injuries, which are divided into three groups:

I. Paralysis of muscular function with partially preserved deep sensation in feet (group B, according to Frankel);

2. severe paresis with preservation of active motions but of no functional importance (corresponding to Frankel's group C);

3. corresponding to Frankel's group D: paresis of insignificant degree, limiting functions of extremities.

As results from the tabulation, the majority of patients (52 per cent) on admission demonstrated signs of complete injury of the spinal cord.

Examining trauma mechanisms, compression fractures were most often found (above 56 per cent of cases), distinguished between crush fractures (accompanied often by relatively insignificant damages to the spinal cord) and those defined as explosion injuries. Such fractures occur after striking the head against a hard object under a small layer of water, especially in patients of considerable weight. Fragments of the crushed body often displace into the vertebral canal, causing, as a rule, significant degree of spinal cord injury. Less frequently, we found spinal injuries due to anterior flexion mechanism, when-after striking the head against the bottom-the head undergoes rapid bending to the thorax. This group is divided in cases with fracture of the anterior part of the body combined with dislocation and those without simultaneous body fracture.

The last, rather rare, mechanism of trauma is extension mechanism. In such cases the diver hits his forehead against the bottom of water reservoir and the head undergoes rapid posterior bending.

\section{Treatment}

In the treatment of the discussed group of cervical spine injuries, both conservative as well as surgical methods have been used.

Table II presents treatment methods taking into consideration previously discussed divisions of trauma mechanisms which was decisive mainly as to the choosing of the treatment method.

In fractures due to flexion mechanism, we used, as a rule ( 74 per cent of cases), skull traction for a period of 6-8 weeks and then, for full stabilization, an orthopaedic collar.

In some cases of lack of spinal stabilisation by conservative treatment, or lack of reduction of body fragment wedging into vertebral canal, we used decompression

TABLE II

\begin{tabular}{|c|c|c|c|c|c|c|}
\hline \multirow[t]{3}{*}{ Treatment method } & \multicolumn{4}{|c|}{ Trauma mechanism } & \multirow{3}{*}{ Extension } & \multirow[t]{3}{*}{ Total } \\
\hline & \multicolumn{2}{|c|}{ Flexion } & \multicolumn{2}{|c|}{ Compression } & & \\
\hline & Fracture & Dislocation & Crush & Explosion & & \\
\hline \multirow{3}{*}{$\begin{array}{l}\text { Orthopaedic collar } \\
\text { Skull traction } \\
\text { Decompression, } \\
\text { spine fusion }\end{array}$} & - & 一 & 6 & - & 3 & 9 \\
\hline & 34 & 7 & 29 & I I & I & 82 \\
\hline & I2 & 23 & - & 56 & - & II \\
\hline
\end{tabular}


and spinal fixation by anterior approach. On the other hand, in dislocation of the spine without fracture, surgical fixation was used obtaining early and full stability.

Insignificant-degree of compression fracture took place rarely in the discussed group of cases. In such traumas, the fracture causes insignificant damage to the spinal cord and sufficient stabilisation of the spine is secured by orthopaedic collar.

In the majority of cases it is necessary to use skull traction. In burst and explosion fractures, pressure to spinal cord by fragments, occurs very often. In this situation we think that the only possibility of neurological improvement may be obtained by early removal of the crushed body followed by fixation from anterior approach. In cases without displacement of vertebral fragments, we use skull traction. Extension fractures have been found very seldom and their course was without displacements. Here, sufficient stabilisation is achieved by orthopaedic collar.

\section{Treatment results}

Table III presents neurological status ascertained on admission to the hospital and after treatment, with age of patients taken into consideration:

Symbol C denotes complete spinal cord injury; consecutive figures I, 2, 3, degree of partial (incomplete) spinal cord injury (previously mentioned); symbol $\mathrm{N}$, the norm, that is, without neurological disturbances. During treatment, improvement has been obtained in 55 per cent of patients. Best results were ascertained in the most numerous group ( 54 per cent) of the youngest patients (improvement in 62 per cent of cases), somewhat worse, in age interval up to 30 years of life, and in successive age intervals improvements were found very rarely. It is, however, difficult to compare these figures, because patients past 30 constitute hardly I I per cent of the group discussed.

TABLE III

\begin{tabular}{|c|c|c|c|c|c|}
\hline \multirow{2}{*}{$\begin{array}{l}\text { Neurologic status } \\
\text { before-after } \\
\text { treatment }\end{array}$} & \multicolumn{4}{|c|}{ Patient age } & \multirow[t]{2}{*}{ Total } \\
\hline & Up to 20 & $2 I-30$ & $3 I-40$ & Over 40 & \\
\hline \multicolumn{6}{|l|}{ Improvement.s } \\
\hline $\mathrm{C}-3$ & 2 & - & - & - & 2 \\
\hline $\mathrm{C}-2$ & 4 & I & - & - & 5 \\
\hline $\mathrm{C}-\mathrm{I}$ & 4 & 2 & I & - & 7 \\
\hline $\mathrm{I}-\mathrm{N}$ & 2 & I & - & - & 3 \\
\hline$I-3$ & I3 & 9 & - & - & 22 \\
\hline $\mathrm{I}-2$ & 5 & 6 & - & - & I I \\
\hline $2-\mathrm{N}$ & 3 & 2 & I & - & 6 \\
\hline $2-3$ & 3 & I & I & - & 5 \\
\hline $3-\mathrm{N}$ & 20 & 6 & I & $\mathbf{I}$ & 28 \\
\hline \multicolumn{6}{|l|}{ Without improvement } \\
\hline $3-3$ & 2 & I & - & - & 3 \\
\hline $2-2$ & I & I & - & - & 2 \\
\hline $\mathrm{I}-\mathrm{I}$ & - & 2 & I & - & 3 \\
\hline $\mathrm{C}-\mathrm{C}$ & 32 & 28 & 6 & - & 66 \\
\hline Deaths & 7 & 4 & 4 & 4 & 19 \\
\hline Total & 98 & 64 & I5 & 5 & 182 \\
\hline
\end{tabular}


Taking into consideration the fact that the analysed group includes a great number of cases with complete or severe (group B according to Frankel) spinal cord injury ( 75 per cent of cases), the results obtained can be considered as satisfactory confirming rightness of accepted tactics.

\section{SUMMARY}

In $1965-1978$, I94 patients with cervical spine injuries, caused by diving into water, were treated. This group constitutes $2 \mathrm{I}$ per cent of treated patients with cervical spine injury in the early post-traumatic period. In I82 cases, spine fracture was accompanied by spinal cord injury. The majority of patients ( 52 per cent) on admission demonstrated signs of complete injury of the spinal cord. During treatment, improvement has been obtained in 55 per cent of patients. Best results were ascertained in the largest group of the youngest patients (improvement in 62 per cent of cases), somewhat worse-in age interval up to 30 years of life, and in successive age intervals improvement was ascertained very rarely.

Taking into consideration the fact that the analysed group includes a great number of cases with complete or deep spinal cord injury ( 75 per cent of cases), the results obtained can be considered as positively confirming rightness of accepted tactics.

\section{RÉSUMÉ}

En I965-I978 on a soigné I94 malades après les traumas de la colonne cervicale, résultants du saut en l'eau. Cette groupe fait $2 \mathrm{I} \%$ traités dans le tôt période posttraumatique des malades avec les fractures de la colonne cervicale. Les I82 cas des fractures de la colonne cervicale. Les I82 cas des fractures de la colonne sont concomitantes avec des lésions de la moelle cervicale. La plupart des malades (52\%) au début de la hospitalization montrait des symptômes de lésions de la moelle. Au cours du traitement on a obtenu l'amélioration neurologique chez $55 \%$ des malades. On a constaté les meilleurs résultats chez les malades les plus jeunes (l'ámelioration dans $62 \%$ des cas), un peu plus pire chez ceux de l'âge de 30 ans environ, chez plus agés, l'amélioration fut plus rare.

En considération du fait, que la groupe analysée contient une grande quantité des cas avec une lésion de la moelle totale ou partiale-nous apprécions que les résultats sont avantageuses, et admettent juste la tactique du procédé.

\section{ZUSAMMENFASSUNG}

In den Jahren 1965-I978 wurden I94 Kranke mit Halswirbelverletzungen infolge eines Sprungs ins Wasser behandelt. Diese Gruppe bildet 21\% der Patienten mit Genickbruch, die kurz nach der Verletzung behandelt wurden. In I82 Fällen war der Genickbruch/Rückgratbruch/mit Verletzung des Rückenmarks verbunden. Die Mehrzahl der Patienten $(52 \%)$, die ins Krankenhaus angenommen wurden, wiesen Symptome einer completten Rückenmarkverletzung auf. Im Laufe der Behandlung erreichte man neurologische Besserung bei $55 \%$ der Kranken. Die verhältnismäßig besten Resultate erreichte man in der größten Gruppe der jüngsten Patienten (62\% der Fälle), ein wenig schlechter stellen sich die Resultate bei Patienten bis zum 30. Alter dar, und bei Patienten in den nächsten Altersabschnitten tritt die neurologische Besserung selten auf.

Wenn in Betracht gezogen wird, daß die Forschungsgruppe aus Fällen mit voller oder schwerer/beträchtlicher/Schädigung des Rückenmarks besteht, können wir die erreichten Ergebnisse der Behandlung als befriedigend bewerten, sie bestätigen die Richtigkeit der angewandten Behandlungsweise.

\section{REFERENCES}

Frankel, H. L., Hancock, D. O., Hyslop, G., Melzak, J., Michaelis, L. S., Ungar, G. H., VERNON, J. D. S. \& WALSH, J. J. (I969). The value of postural reduction in the initial management of closed injuries of the spine with paraplegia and tetraplegia. Paraplegia, 7, I79. 
Hall, J. C. (1978). Diving injury resulting in tetraplegia. Med. F. Aust. I, I7I.

SELECKI, B. R. \& Williams, H. B. L. (I970). Injuries to the cervical spine and cord in man. Australasian Med. Publishing Company, Sydney.

VERBIEST, H. (I969). Anterolateral operations for fractures and dislocations of the cervical spine. F. B. F. Surg. $(\mathrm{Am}), \mathbf{5 1}$, I489.

WilcoX, N. E., STAUFFER, E. S. \& NICKEL, V. L. (1970). A statistical analysis of 423 consecutive patients admitted to the Spinal Cord Injury Center Rancho Los Amigos Hospital. Paraplegia, 8, 27. 